\title{
The Evaluation of the Bark Beetles Populations on Spruce Logging Debris
}

\author{
Ciprian G. FORA ${ }^{1 *}$, Karl F. LAUER ${ }^{1}$, Mihaela M. MOATĂR ${ }^{1}$ and Sorin STANCIU ${ }^{2}$ \\ ${ }^{1}$ Faculty of Horticulture and Forestry, University of Agricultural Sciences and Veterinary Medicine \\ "King Michel I of Romania" from Timişoara, Calea Aradului 119, 300645, Romania \\ ${ }^{2}$ Faculty of Agricultural Management, University of Agricultural Sciences and Veterinary Medicine \\ "King Michel I of Romania" from Timişoara, Calea Aradului 119, 300645, Romania \\ *)Corresponding author, e-mail: foraciprian@yahoo.com
}

BulletinUASVM Horticulture 72(2) / 2015

Print ISSN 1843-5254, Electronic ISSN 1843-5394

DOI:10.15835/buasvmcn-hort:11365

\begin{abstract}
Today, when somebody is talking about bark beetles management, there are two different approaches. The first one includes bark beetles in the category of pests and the second one includes bark beetles in the category of insects with important ecologic role in forest. From our point of view, up to particular limits, both approaches remain valid. Thus, in our research raise the problem of bark beetles population level into logging debris, which remains in the forest after clear-cutting. In our research, we started with the hypothesis that in logging debris a high number of bark beetles can multiply sufficient to install after that in neighbors standing trees. From our samples resulted seven bark beetles species as follows: Ips typographus, Ips amitinus, Ips acuminatus, Pityogenes chalcographus, Dryocoetes autographus, Hylurgops palliatus, Hylurgops glabratus. The most numerous were I. typographus (43\%), P. chalcographus (40\%), and H. palliatus (9\%). The preferences for the thickness of logging debris had just $P$. chalcographus and H. palliatus. All the rest of the species preferred in equal mode thick or thin logging debris. Regarding the felling date of trees, we can affirm that cutting of trees early in spring may limit the beetles spreading. About logging debris management, our results show the necessity of their removal from forest and capitalization, because they are hosts for many bark beetles.
\end{abstract}

Keywords: bark beetles, development, spruce, logging debris, management.

\section{INTRODUCTION}

The spruce is one of the most important species in the forest stands of Romania due to its spread, high value and multiple uses (Şofletea and Curtu, 2007). Bark beetles (Coleoptera, Curculionidae, Scolytinae) are of fundamental importance for forest ecosystems because they are the first in decomposing wood of dying or recently dead trees and are an important rejuvenating agent in natural forests (Dworschak, 2013). By creating dead wood and forest gaps, they facilitate fungal, insect and plant diversity (Müller et al., 2008; Müller et al., 2010; Wermelinger, 2004).
At the same time, bark beetles can cause serious damage in standing trees when they excessively multiply (Lieutier, 2004; Simionescu et al., 2003). Weslien et al. (1989) reported that the risk of the trees to be kill by Ips typographus (L.) increase in the same time with bark beetles multiplication.

Although the bark beetles were studied in the past in detail, in recent years could be observed an increased interest of researchers on this topic, including in our country, due to new issues appeared, Duduman and Vasian (2012), Fora et al. (2014), Isaia et al. (2010), Oltean (2003). Currently in Romania, spruce logging is making by clear- 
cutting on surfaces, which did not exceed three ha, to limit the negative effects that may result from this practice (Chisăliță et al., 2014). As result of logging, in felling area there remains a number of logging debris, which is favorable place for bark beetles installation and development. From here, the resulting beetles can infest nearby standing trees (Lobinger, 1994) creating, in many times, uncontrollable outbreaks especially in restricted areas. In this context, given the assumption that a number of bark beetles succeed to complete their life cycle on logging debris, in our research we want to identify which species are, which is the level of population of each species and their level of participation from total number of caught bark beetles. The knowledge of these elements may be an additional argument for the measure of removal from forest and capitalization of logging debris in the management process to minimize the risk of attack standing trees.

\section{MATERIALS AND METHODS}

Study site. The research was conducted in 2012 in three sites of managed forests in Natural Park Apuseni, located in the Western Romanian Carpathians, where local practice includes clear-cutting system with natural and artificial regeneration. Amean annual temperature of $8-10^{\circ} \mathrm{C}$ and an average annual rainfall of approximately 800-1200 mm characterize the climate. The main forest species in area are Picea abies (90\%), Abies alba (5\%), Larix decidua (3\%). The first study site was Groapa de la Barsa (46³5'7.59”N and $22^{\circ} 40^{\prime} 29.71^{\prime \prime} \mathrm{E}$ ) of $1.32 \mathrm{ha}$, between 1180-1200 $\mathrm{m}$ in elevation and located on a northwest-facing slope with a gradient of approximately 20\%. The second study site was Tomantec (46 $37^{\prime} 54.53^{\prime \prime} \mathrm{N}$ and $22^{\circ} 44^{\prime} 21.95^{\prime \prime}$ ) 0.95 ha, between 1180-1200 $m$ in elevation and located on a north-facing slope with a gradient of approximately $20 \%$. The third study site was Călineasa (46³4'24.49”N $\mathrm{N}$ and 22.49'27.99"E) 1.50 ha, between 1490-1500 $\mathrm{m}$ in elevation and located on a west-facing slope with a gradient of approximately 30\%. The age of stand was between 115 and 120 years when the final felling was conducted.

Sampling. After clear-cutting of wood mass in spring (12 March in Groapa de la Barsa; 23 April in Tomnatec; 15 May in Călineasa), the spruce logging debris remains in felling area in piles of approximately $2 \mathrm{~m}$ width and $1.5 \mathrm{~m}$ height with different length, piles from which were taken the samples after 2 weeks. Before sampling each study areas were split in four sections and from every part there were taken two different kinds of samples. The first category was with diameter of 22-26 cm and $1 \mathrm{~m}$ length (thick parts), and the second category with diameter of 4-10 cm and $1 \mathrm{~m}$ length (thin parts). For choosing of samples was taken into consideration that the main pest I. typographus prefer for oviposition spruce with diameter more than $22 \mathrm{~cm}$ (Zurm, 1985) and $P$. chalcographus prefer for oviposition spruce with diameter less than $15 \mathrm{~cm}$ (Stolina, 1969). In total there were collected 24 samples from the middle of the piles according to described personal method. The samples were added in PE tubes (eclectors). The PE tubes have on top plastic mesh for ventilation and on base a large funnel with a pot which contained ethanol 70\% (Feicht 2004, 2006). PE tubes were hung on the shadow of the building from Ic Ponor and controlled until the end of September. All collected insects were sorted and identified in Forest Entomology Laboratory from Faculty of Horticulture and Forestry Timișoara by the author.

Statistical analyses. Because the diameter of the wood samples was not equal to each other and consequently the surface of bark was different, before statistical analysis, the data taken from field were adjusted and expressed on 1 sqm of bark. Only the species whose number was more than 50 individuals were considered. For every species in part there was calculated the arithmetic average of obtained values. The result is the average number of beetles related to 1 sqm of bark, for the readings corresponding to the above-mentioned observation periods. In addition, it was calculated confidence interval of mean for all species. It was checked the existence of any differences between recorded beetles on wood material with diameters between $22-26 \mathrm{~cm}$ and $4-10 \mathrm{~cm}$ respectively the total dimension of captures made in different locations. To this was calculated t-Test (TwoSample Assuming Equal Variances), p values (twotail) are shown in table 1 and figure 2.

\section{RESULTS AND DISCUSSION}

In all 24 analyzed samples of spruce debris were caught 30.219 bark beetles, 13.482 provided from samples with diameter of $22-26 \mathrm{~cm}$ and 16.737 provided from samples with diameter of 
4-10 cm. In total there were identified 7 species of bark beetles: Ips typographus, Ips amitinus, Ips acuminatus, Pityogenes chalcographus, Dryocoetes autographus, Hylurgops palliatus, Hylurgops glabratus (Fig. 1). I. typographus represented $43 \%$ from all beetles, I. amitinus $5 \%$, I. acuminatus $1 \%$, P. chalcographus $40 \%$, D. autographus $1 \%$, H. palliatus 9\%, Hylurgops glabratus 1\%. In thick samples $I$. typographus was most abundant followed by $H$. palliatus and $P$. chalcographus. In thin samples $P$. chalcographus was most abundant followed by I. typographus and I. amitinus. In samples of 22-26 cm the number of I. typographus beetles was almost 4 times higher than the number of $P$. chalcographus and in samples of 4-10 cm the number of $P$. chalcographus beetles was just almost 2 times greater than the number of I. typographus (figure 2).

From the point of view of logging debris diameter, the thickness of it significantly influences the $P$. chalcographus and $H$. palliatus population level (Fig. 2). P. chalcographus significantly prefer thin logging debris with the diameter of $4-10 \mathrm{~cm}$. This observation is in accordance with Stolina (1969). In opposition $H$. palliatus significantly prefer thick logging debris with the diameter of 22$26 \mathrm{~cm}$. Interesting was the fact that I. typographus preferred thick and thin logging debris too, the differences being insignificant. That means $I$. typographus in our study found good conditions on all types of logging debris, in contrast to results obtained by Zurm (1985). I. amitinus, I. acuminatus, D. autographus and Hylurgops glabratus, prefer both thick and thin logging debris, the differences being insignificant.

The establishment of felling date for practice has an important role in bark beetles management. In our study, the felling date had strong effect on recorded bark beetles in PE tubes (Tab. 1). The most abundant species were in Groapa de la Barsa which was clear-cut in 12 of March, followed by Tomnatec (clear-cut in 23 of April) and final by Călineasa (clear- cut in 15 of May).

I. typographus, $\mathrm{p}=0.367523 ;$ I. amitinus, $\mathrm{p}=0.856131 ; \quad$ I. acuminatus, $\mathrm{p}=0.190500 ; \quad P$. chalcographus, $\mathrm{p}=0.014103 ; \quad D$. autographus, $\mathrm{p}=0.017933 ; H$. palliatus, $\mathrm{p}=0.272593 ; H$. glabratus, $\mathrm{p}=0.190743$. Mean values in the same clustered column followed by the same letter do not differ significantly at $\mathrm{p}=0.05$ ( $\mathrm{t}$-Test)

The number of beetles occurred from our samples decreased with the delay of felling date in spring. This result may be due to the fact that a part of beetles flew from trees before they were cut. Consequently cutting delay in spring increase the risk of beetles spreading. Our results show that the risk of pests multiplication may be minimized if the feeling date was conducted in early spring. Similarly, Foit (2015) found significantly influence of Pinus sylvestris felling date on bark beetles

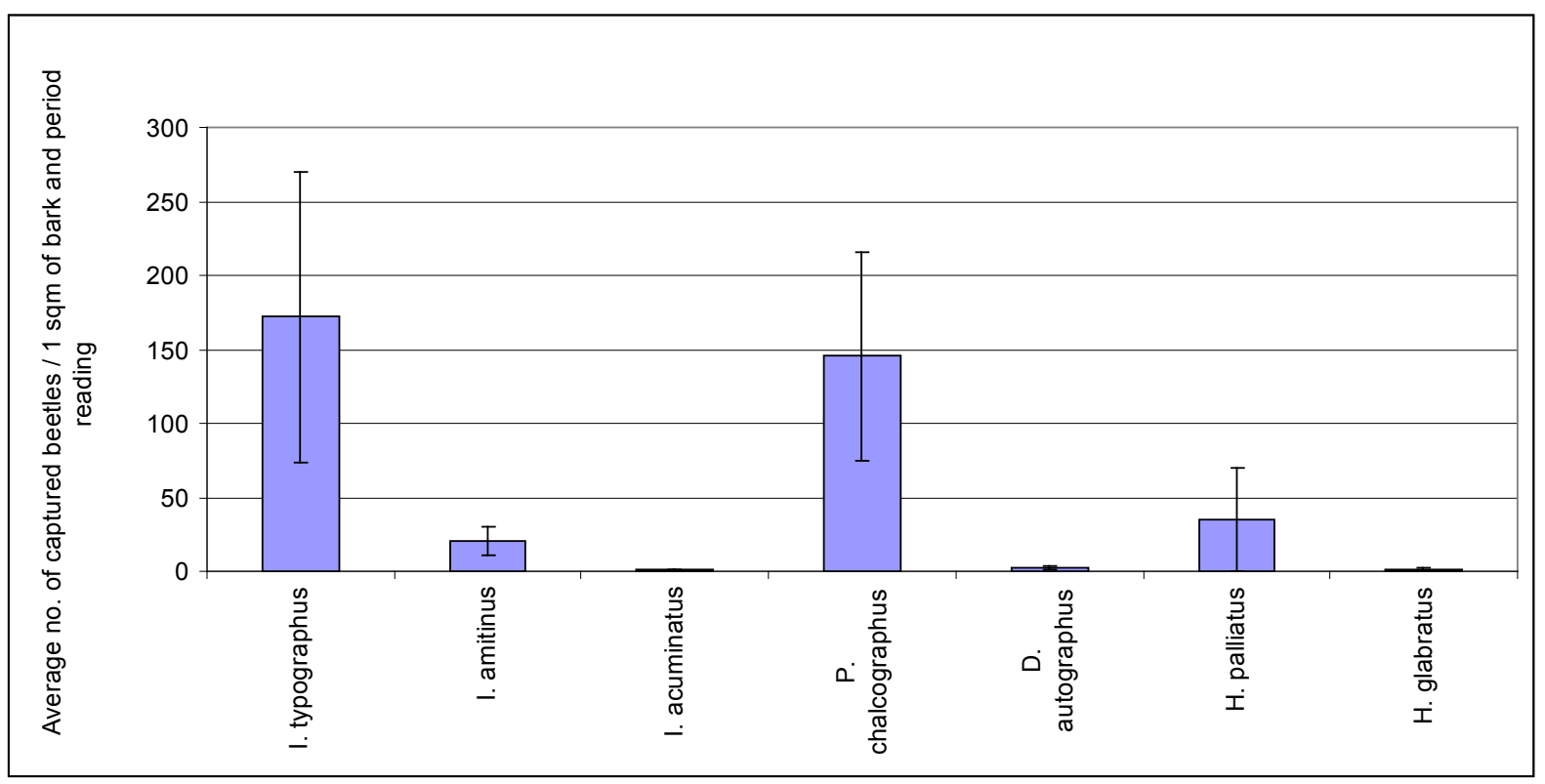

Fig.1. The bark beetles occurrence on all samples. 


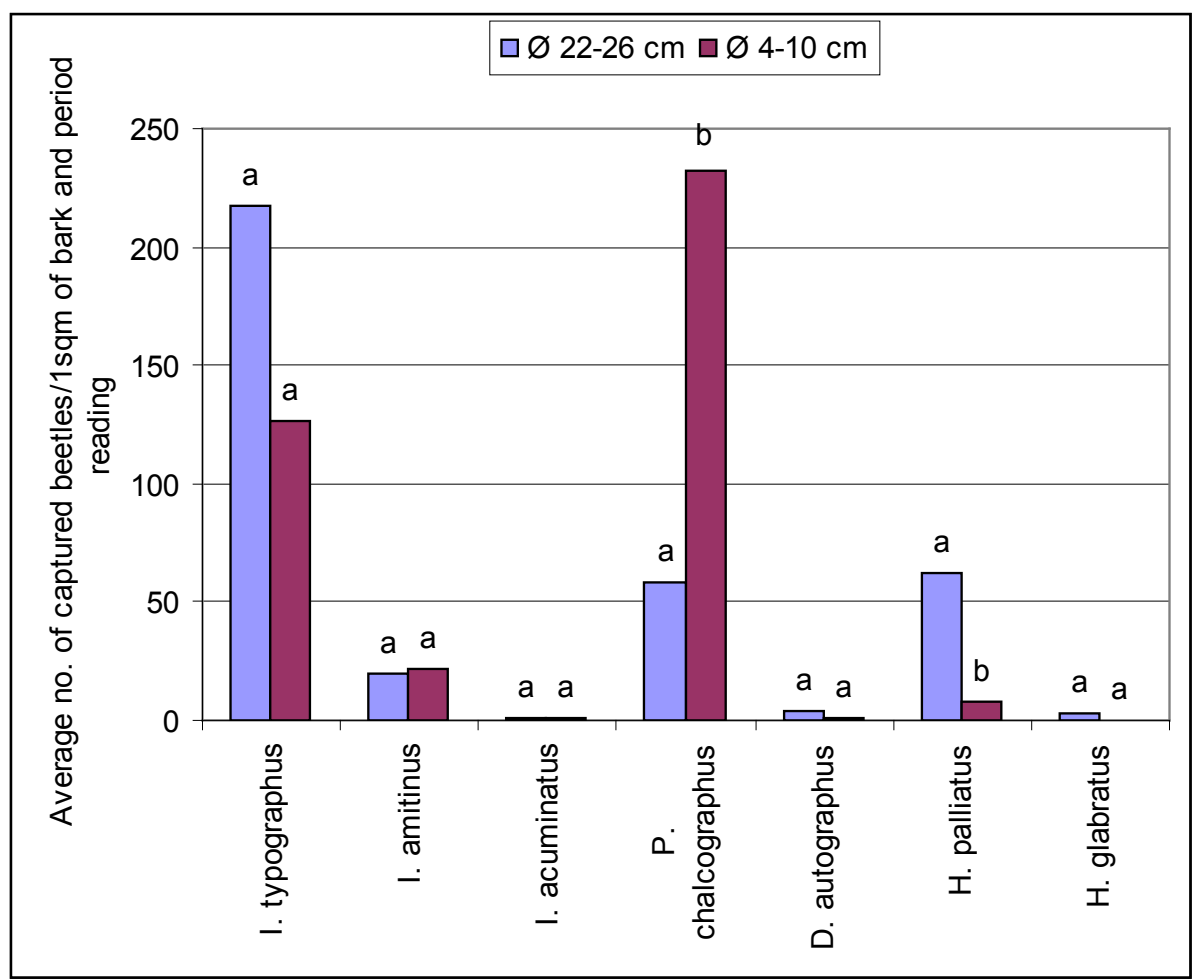

Fig. 2. The comparison between bark beetles number and the thickness of infested wood.

Tab. 1. The comparison between bark beetles number in studied areas

\begin{tabular}{|c|c|c|c|}
\hline Locations & $\begin{array}{c}\text { Groapa de la Barsa - } \\
\text { Tomantec }\end{array}$ & $\begin{array}{l}\text { Tomantec - } \\
\text { Călineasa }\end{array}$ & $\begin{array}{c}\text { Groapa de la Barsa - } \\
\text { Călineasa }\end{array}$ \\
\hline $\mathrm{p}$ (tw & 0,001111 & 0,02828 & $7,29 * 10^{-05}$ \\
\hline Signif & $\begin{array}{l}\text { There exist significant } \\
\text { differences, mean number of } \\
\text { beetles from area "Groapa de } \\
\text { la Barsa" is superior to mean } \\
\text { number of beetles from area } \\
\text { „Tomnatec" }\end{array}$ & $\begin{array}{l}\text { There exist significant } \\
\text { differences, mean number } \\
\text { of beetles from area } \\
\text { "Tomnatec" is superior to } \\
\text { mean number of beetles } \\
\text { from area } \\
\text { „Călineasa” }\end{array}$ & $\begin{array}{l}\text { There exist significant } \\
\text { differences, mean number of } \\
\text { beetles from area "Groapa de } \\
\text { la Barsa" is superior to mean } \\
\text { number of beetles from area } \\
\text { „Călineasa" }\end{array}$ \\
\hline
\end{tabular}

occurrence. At the same time, the estimation of bark beetles population density is of high theoretical and practical significance for nature and forest conservation (Borkowski and Podlaski, 2011). In the last years, more and more authors pay attention to ecological role of bark beetles as ecosystem engineers and keystone species, influencing forest regeneration and conversion (Müller et al., 2008).

Many researches show that trees on the south slope and trees exposed to sunlight were preferentially attacked by bark beetles, especially after the sudden rise of solar radiation (Lobinger and Skatulla, 1996; Jakus, 1998). In our case, highest level of captures was record on logging debris provided from trees which were on NordWest or Nord slope. As regarding elevation, in our conditions, the level of bark beetles population was lower at 1490-1500 m than 1180-1200m.

Our hypothesis that in spruce logging debris survives and develops a large number of bark beetles is confirmed. This fact underlines the necessity of removal from forest and capitalization 
of logging debris in the management process, to minimize the risk of attack standing trees.

\section{CONCLUSION}

Logging debris provided a substrate for the development of a large number of bark beetles in the present study. In logging debris there were present 7 species of bark beetles: I. typographus, I. amitinus, I. acuminatus, P. chalcographus, D. autographus, $H$. palliatus, $H$. glabratus. The dominant bark beetles species were I. typographus, $P$. chalcographus and $H$. palliatus with a percentage of participation in population by $43 \%, 40 \%$ respectively 9\%. I. typographus was present on thick or thin logging debris, the differences being unsignificant. $P$. chalcographus prefers thin logging debris and $H$. palliatus thick logging debris. I. amitinus, I. acuminatus, D. autographus and Hylurgops glabratus, prefer both thick or thin logging debris. The risk of the pests multiplication could be minimized through removal from forest and capitalization of logging debris in the management process. Felling date in early spring decrease the risk of bark beetles spreading in remains standing trees.

Acknowledgments. This study was financed by the project "Postdoctoral School in Agriculture and Veterinary Medicine", POSDRU/89/1.5/S/6237, co-financed by the European Social Fund, through Sectorial Operational Programme for Human Resources Development 2007-2013. We thank to the administration of Natural Park Apuseni for technical support and general permission.

\section{REFERENCES}

1. Borkowski A, Podlaski R (2011). Statistical evaluation of Ips typographus population density: a useful tool in protected areas and conservation-oriented forestry. Biodivers Conserv 20:2933-2951.

2. Chisăliță I, Stanciu S, Ștefan C, Moatăr M, Fora C.G, Vișoiu D (2014). Research on the development of technical standards in logging process - a diagnostic analysis. Scient Res Agr Manag 16(3):77-83.

3. Duduman M.L, Vasian I (2012). Effects of volatile emissions of Picea abies fresh debris on Ips duplicatus response to characteristic synthetic pheromone. Not Bot Hort Agrobot 40(1):308-313.

4. Dworschak K (2013). Ecophysiology of the European spruce bark beetle (Ips typographus L.): Factors affecting individual fitness, dispersal and population dynamics. Dissertation 129 pp.
5. Feicht E (2004). Parasitoids of Ips typographus (Col., Scolydidae), their frequency and composition in uncontrolled and controlled infested spruce forest in Bavaria. J Pest Sci 77:165-172.

6. Feicht E (2006). Frequensy, species composition and efficiency of Ips typographus (Col., Scolydidae) parasitoids in infested spruce forests in the National Park "Bavarian Forest" over three consecutive years. J Pest Sci 79:35-39.

7. Foit J (2015). Bark- and wood-boring beetles on Scots pine logging residues from final felling: effects of felling date, deposition location and diameter of logging residues. Ann. For. Res. 58(1):67-79.

8. Fora C.G, Banu C, Chisăliță I, Moatăr M, Oltean I (2014). Parasitoids and predators of Ips typographus (L.) in unmanaged and managed spruce forests in Natural Park Apuseni, Romania. Not Bot Horti Agrobo 42(1):270-274.

9. Isaia G, Manea A, Paraschiv M (2010). Study on the effect of pheromones on the bark beetles of the Scots pine. Bull of the Transilvania Univ of Brasov 52(3):67-72.

10. Jakus R (1998). Types of bark beetles (Coleoptera: Scolyttidae) infestation in spruce forest stands affected by air polution, bark beetle outbreak and honey fungus (Armillaria mellea). Anz Schädlingskde Pflanzenschutz Umveltschutz 71:41-49.

11. Lieutier F (2004). Host resistance to bark beetles and its variations. In: Lieutier F, Day KR, Batissti A, Gregoire JC, Evans HF (Eds) Bark and Wood Borring Insects in Living Trees in Europe, a Synthesis. Kluwer Academic Publishers, London 135-180.

12. Lobinger G (1994). The air temperature as a limiting factor for the swarming of two spruce bark beetles, Ips typographus L. and Pityogenes chalcographus L. (Col., Scolytidae). Anzeiger für Schädlingskunde, Pflanzenschutz, Umweltschutz 67(1):14-17 (in German).

13. Lobinger G, Skatulla U (1996). Influencing the flight behaviour of bark beetles by light conditions. Anz Schädlingskde Pflanzenschutz Umveltschutz 69:183-185. (in German)

14. Müller J, Bußler H, Goßner M, Rettelbach T, Duelli $P$ (2008). The European spruce bark beetle Ips typographus in a national park: from pest to keystone species. Biodiv and Conserv 17:2979-3001.

15. Müller J, Noss RF, Bussler H, Brandl R (2010). Learning from a "benign neglect strategy" in a national park: response of saproxylic beetles to dead wood accumulation. Biol Conserv 143: 2559-2569.

16. Oltean I (2003). Studies related to the bark pests dynamics in the forests of the Dorne area. J Cent Eur Agr 4(3):251256.

17. Simionescu A, Mihalache Gh, Mihalciuc V, Ciornei C, Olenici N, Chira D, Lupu D, Nețoiu C, Vlăduleasa A, Iliescu M, Vișoiu D, Chira F, Rang C, Tăut I, Mihai D (2003). Forest protection. Musatinii Publishing House, Suceava. 867 pp. (in Romanian)

18. Şofletea N, Curtu L (2007). Dendrology. Ed. Transilvania, Brașov. 419 pp. (in Romanian) 
19. Stolina M (1969). The influence of bark beetles to development of structure of natural montainous forests in Western Carpathians. Lesnícky ćasopis. 15(1):45-63.

20. Wermelinger B (2004). Ecology and management of the spruce bark beetle Ips typographus - a review of recent research. Forest Ecology and Management 202:67-82.
21. Weslien J, Annila E, Bakke A, Bejer B, Eidmann HH, Narvestad K, Nikula A, Ravn HP (1989). Estimating risk for spruce bark beetle (Ips typographus (L.)) damage using pheromone-baited trap and trees. Scan J For Res 4:87-98.

22. Zurm V (1985). Biology and ecology of spruce bark beetle (Ips typographus) and its control. Academia. 124 pp. 